Jurnal Intelektualita: Keislaman, Sosial, dan Sains Volume 7, Nomor 1, Juni 2018 ISSN: 2303-2952 (print)

DOI: https://doi.org/10.19109/intelektualita.v7i1.2342

\title{
Kekuatan Bukti Elektronik Sebagai Bukti di Pengadilan Menurut Hukum Acara Pidana dan Hukum Islam (Penggunaan Rekaman Gambar closed Circuit Television)
}

\author{
Darus Harizona \\ Fakultas Syariah dan Hukum \\ Universitas Islam Negeri Raden Fatah Palembang \\ Email: darusharizona_uin@radenfatah.ac.id
}

\begin{abstract}
Abstrak
Pengunaan Closed Circuit Television demi kepentingan pengamanan bagi sebagian masyarakat sudah semakin sering digunakan. Hal ini dibuktikan dengan beberapa berita di surat kabar contohnya: Pelaku kejahatan pencurian terekam CCTV dimini market pelaku berjumlah dua orang masuk kedalam toko. (Palembang Ekspres. 27 Oktober 2016), meningkatkan pelayanan kepada pengguna jasa KA Kertalaya saat ini, KA tujuan Kertapati-Indralaya telah dilengkapi CCTV. (Harian Sumatera Ekspres. 24 Nopember 2014), bermodalkan hasil rekaman CCTV anggota polisi, menangkap M Herman. Pelaku pencurian motor. (Berita Pagi. 26 Agustus 2016). Melihat fakta-fakta yang ada bahwa CCTV bisa digunakan untuk merekam semua kejadian, hal ini tentu dapat membantu para penyidik untuk menemukan tersangka apabila terjadi tindak pidana yang terekam. Akan tetapi, CCTV bukan lah alat bukti yang sah sebagaiman KUHAP Pasal 184 sebutkan bahwa alat bukti yang sah adalah keterangan saksi, keterangan ahli, surat, pentujuk, keterangan terdakwa. Maka dalam hal ini penulis melakukan penelitian yang berjudul: kedudukan bukti elektronik sebagai bukti di pengadilan menurut Hukum Acara Pidana dan Hukum Islam (penggunaan rekaman gambar Closed Circuit Television). Penulis dalam hal ini, menggunakan metode penelitian yang bersifat yuridis normative yaitu mengacu pada norma hukum serta peraturan perundang-undangan dan putusan pengadilan serta norma-norma yang hidup yang berkembang dalam masyarakat. Penulis dalam penelitian ini menggunakan alat pengumpulan data yaitu menggunakan penelitian kepustakaan sebagai data primer dan sekunder. Serta wawancara langsung terhadap responden yang berkaitan langsung dengan objek penelitian penulis sebagai data penunjang. Penulis dalam menganalisa data menggunakan analisa deskriptif analitis yaitu menentukan isi atau makna aturan hukum yang dijadikan rujukan dalam meyelesaikan permasalahan hukum. Penelitian yang penulis temukan bahwa CCTV adalah alat bukti namun bukanlah alat bukti yang berdiri sendiri tetapi ditentukan sendiri oleh hakim dengan ukuran yuridis, filosofis dan sosiologis. Oleh karena itu, penulis berharap dengan melakukan penelitian ini dapat menambah pengetahuan di bidang ilmu hukum serta penggunaan CCTV tidak lagi menjadi sebuah persoalan hukum dan dapat terus digunakan sebagai alat keamanan di masyarakat.
\end{abstract}

Kata Kunci: Bukti Elektronik, closed Circuit Television

Hukum Pidana adalah hukum yang menentapkan perbuatan apa saja yang dilarang dan menetapakan sanksi bagi yang melakukan perbuatan [1]. Hukum Pidana di Belanda memakai istilah strafbaar feit [2]. Menurut A. Z. Abidin istilah strafbaar feit adalah 


\section{Darus Harizona}

Kekuatan Bukti Elektronik Sebagai Bukti di Pengadilan Menurut Hukum Acara Pidana dan Hukum Islam (Penggunaan Rekaman Gambar closed Circuit Television)

"delik" yang umum dipakai oleh para sarjana. Simons merumuskan delik (strafbaar feit) adalah kelakuan yang diancam dengan pidana yang bersifat melawan hukum berhubungan dengan kesalahan dan dilakukan orang yang mampu bertanggung jawab.

Delik (strafbaar feit) memiliki unsur subyektif syarat pemidanaan yaitu unsur kesalahaan dalam arti luas meliputi delik sengaja dan delik kelalaian atau culpa (Doleuse en culpose deliten) dan melawan hukum sebagai unsur obyektif yang diatur Kitab undang-Undang Hukum Pidana (KUHP). Sengaja (opzet) adalah kehendak yang disadari yang ditujukan untuk melakukan kejahatan, antara lain diatur dalam Pasal 340 KUHP tentang pembunuhan berencana dan Pasal 355 penganiayaan berat.

Delik kelalaian atau culpa menurut Hazewinkel-Suringa culpa itu terletak antara sengaja dan kebetulan. Vos membedakan unsur culpa, pertama ialah terdakwa dapat melihat kedepan apa yang akan terjadi, kedua ketidak hati-hatian (tidak dapat dipertanggung jawabkan) perbuatan yang dilakukan (pengabaian). Culpa yang menimbulkan akibat yang diancam pidana seperti Pasal 359 kematian dan luka-luka akibat kelalaian.

Perbuatan melawan hukum adalah perbuatan yang bertentangan dengan Hukum Tertulis berdasarkan (nullum crimen sine lege stricta) Pasal 1 ayat (1) KUHP yang berbunyi:

"suatu perbuatan tidak dapat di pidana, kecuali berdasarkan kekuatan undangundang pidana yang telah mengatur”.

Peniadaan pidana dapat menghapus pertanggung jawaban suatu delik (strafbaar feit) dalam KUHP yang diatur, Pasal 44 KUHP perbuatan yang tidak dapat dipertanggung jawabkan karena jiwanya cacat. Pasal 45 KUHP, Pasal 46 KUHP dan Pasal 47 KUHP karena yang melakukan perbuatan belum berumur enam belas tahun. Pasal 48 KUHP dan Pasal 49 KUHP karena pengaruh daya paksa. Pasal 50 KUHP, Pasal 51 KUHP dan Pasal 52 KUHP melakukan perbuatan karena melaksankan ketentuan undang-undang.

Tujuan Hukum Pidana menurut Oemar Seno Adji adalahuntuk membalas kesalahan dan mengamankan masyarakat [2]. Sedangkan menurut Rancangan Undang-Undang KUHP Pasal 5, yaitu:

1. Mencegah dilakukanya tindak pidana dengan menegakkan norma hukum demi pengayoman masyarakat

2. Mengadakan koreksi terhadap terpidana dan dengan demikian menjadikannya orang baik dan berguna

3. Menyelesaikan konflik yang ditimbulkan oleh tindak pidana, memulihkan keseimbangan dan mendatangkan rasa damai dalam masyarkat

4. Membebaskan rasa bersalah pada terpidana

Sedangkan Hukum Islam bertujuan untuk memenuhi kepentingan kebahagian, kesejahteraan, dan keselamatan hidup manusia didunia dan diakhirat. Oleh karena itu, 
apabila Hukum positif yang tidak berdasarkan Alquran dan Alsunnah dikahwatirkan tidak memenuhi tujuan Hukum Islam maka ditemukan bahwa tujuan Hukum Islam lebih tinggi dan abadi. Hukum Islam dimaksudkan agar kebaikan mereka semua dapat terwujud [3].

Hukum pidana Islam diterjemahkan dari Istilah fiqh Jinayah didefinisikan secara lengkap meliputi dua kata pokok, yaitu fiqh dan jinayah. Fiqh adalah ilmu tentang hukum-hukum syariah yang bersifat praktis dan merupakan hasil mujtahid terhadap dalil-dalil yang terperinci, baik yang terdapat dalam al-Qur'an dan al-Hadist. Adapun istilah Jinayah berasal dari Bahasa Arab, berasal dari kata jana-yajni-janyan-jinayatan yaitu berarti adznaba (melakukan dosa) [4].

Hukum Pidana objektif adalah peraturan hukum yang jika dilanggar, pelakunya dapat diancam pidana [5]. Hukum Pidana objektif dibagi dalam Hukum Pidana Materiil dan Hukum Pidana Formil. Hukum Pidana materiil ialah peraturanyang menegaskan, perbuatan yang dapat dihukum, siapa yang dapat dihukum, dengan hukuman apa menghukum seseorang. Singkatnya hukuman Pidana materiil mengatur rumusan dari kejahatan serta syarat bila seseorang dapat dihukum.

Hukum Pidana Formil ialah hukum yang mengatur cara-cara menghukum seseorang yang melanggar peraturan pidana (merupakan pelaksanaan dari hokum Pidana Materiil).

Penjelasan diatas dapat diketahui penyelidikan merupakan tindakan tahap pertama permulaan sebelum penyidikan. Sebagai usaha mencari dan menemukan suatu peristiwa pidana untuk dapat atau tidak dilakukan penyidikan. Tindakan penyidikan lebih dititik beratkan pada tindakan mencari dan mengumpulkan bukti yang diatur dalam KUHAP Pasal 5 ayat (1) huruf b. Tindakan itu berupa penangkapan, penahanan, penggeledahan, penyitaan, pemeriksaan surat.Supaya tindak pidana yang ditemukan menjadi terang agar dapat menemukan dan menentukan tersangkanya.

Pasal 1 butir 20 KUHAP, penangkapan adalah suatu tindakan penyidik berupa pengekangan sementara watu kebebasan tersangka atau terdakwa apabila terdapat cukup bukti guna kepentingan penyidikan atau penuntutan dan atau pradilan dalam hal dan menurut cara yang diatur oleh undang- undang ini.

Pasal 1 butir 21 KUHAP, penahanan adalah penempatan tersangka atau terdakwa di tempat tertentu oleh penyidik atau penutut umum atau hakim dengan penetapannya, dalam hal dan menurut cara yang diatur undang- undang.

Pasal 1 butir 17 KUHAP, penggeledahan rumah adalah tindakan penyidik untuk memasuki rumah tempat tinggal dan tempat tertutup untuk melakukan tindakan pemerikasaan dan atau penyitaan dana atau penangkapan dalam hal dan menurut cara yang diatur undang-undang.

Sedangkan penggeledahan badan diatur dalam pasal 1 butir 18 KUHAP yang berbunyi: penggeledahan badan adalah tindakan penyidik untuk mengadakan 


\section{Darus Harizona}

Kekuatan Bukti Elektronik Sebagai Bukti di Pengadilan Menurut Hukum Acara Pidana dan Hukum Islam (Penggunaan Rekaman Gambar closed Circuit Television)

pemeriksaan badan dan atau pakaian tersangka untuk mencari benda yang diduga keras ada pada badan nya serta untuk disita.

Pasal 1 butir 16 KUHAP, penyitaan adalah serangkaian tindakan penyidik untuk mengambil ahli dan atau menyimpan dibawah penguasaanya benda bergerak atau tidak bergerak, berwujud atau tidak berwujud untuk kepentingan pembuktian dalam penyidikan, penuntutan, dan peradilan.

Pasal 47 KUHAP, disebutkan bahwa penyidik berhak membuka, memeriksa, dan menyita surat lain yang dikirim melalui kantor pos dan telekomunikasi, jawatan atau perusahaan telekomunikasi atau pengangkutan.

Tindakaan penyidikan yang diatur diatas tidak lain adalah untuk menemukanbuktisebagai syarat menjatuhkan pidana yang diatur Pasal 183

KUHAP berbunyi sebagai berikut:

"Hakim tidak boleh menjatuhkan pidana kepada seorang kecuali dengan sekurang-

kurangnya dua alat bukti yang sah, ia memperoleh keyakinan bahwa suatu tindak

pidana benar-benar terjadi dan bahwa terdakwalah yang melakukannya”.

Dengan demikian, apabila melihat pada Pasal 183 KUHAP diatas maka hakim dalam menjatuhkan pidana paling tidak minimal menggunakan 2 alat bukti yang cukup sehingga dapat membangun keyakinan hakim. Sementara itu alat bukti yang sah menurut Undang-UndangNo. 8 tahun 1981 Tentang KitabUndang- undang Hukum Acara Pidana (KUHAP). Pasal 184 ayat (1) KUHAP, adalah 1) Keterangan saksi; 2) Keterangan ahli; 3) Surat; 4) Petunjuk; dan 5) Keterangan terdakwa.

Sedangkan mengenai pembuktian dalam hukum Islam, tidak berbeda dengan sistem dalam hukum barat. Hakim wajib di beri kesempatan untuk sampai kepada suatu kebenaran. Di ringkasakan oleh Imam Ibnul Qayim Al Jauzy dalam kitab I'lamul Muwaqqi'in berliau berkata:

"sesungguhnya syari' tidaklah membatasi pengambilan keputusan untuk memelihara hak-hak semata-mata berdasarkan kesaksian dua orang saksi laki-laki saja, baik mengenai darah, harta had, bahkan khulafaur rasyisin dan sahabat r.a. telah menghukum had pada zina dengan adanya bukti kehamilan dan pada minum khamar dengan adanya baud an muntah" [6].

Hakim dalam hal ini harus mengetahui apa yanag terjadi dan kemudian memutusakan perkara. Maka bagi hakim memutuskan berdasarkan keadilan.Rasullah s.a.w juga pernah memutuskan dengan seorang saksi dan sumpah menurut Ibnu Abbas r.a.dan juga hakim boleh memutuskan dengan pengakuan saja.

Alat bukti dalam Hukum pidana Islam menurut Usman Hasyim dan Ibnu Rachman adalah yaitu 1) Saksi (Ar-Syahadah); 2) Pengakuan (Al-Iqrar); 3) Tanda-tanda (Alqarain); 4) Penetahuan Hakim ( Maklumatul Qadli); 5) Tulisan/surat ( Al Kitabah); dan 6) Sumpah (Al yamin) [6]. 
Berkenaan Pasal 184 KUHAP diatas menujukan ada 5 alat bukti yang sah.Selain itu alat bukti dalam hukum pidana Islam hanya ada 7. Namun yang menjadi persoalan adalah apabila ada alat bukti yang digunakan diluar ketentuan.

Pasal 184 KUHAP dan Hukum Pidana Islamhal ini dapat penulis contohkandalam persoalan barang bukti elektronik khususnya rekaman gambar Closed Circuit Television (CCTV) yang semakin sering digunakan masyarakat. Masyarakat beranggapan bahwa CCTV bisa digunakan untuk kepentingan pengamanan disaat timbul tindak kejahatan, hal ini dapat penulis beri contoh sebagai berikut:

1. Pelaku kejahatan pencurian terekam CCTV dimini market pelaku berjumlah dua orang masuk kedalam took [7].

2. Meningkatkan pelayanan kepada pengguna jasa KA Kertalaya saat ini, KA tujuan Kertapati-Indralaya telah dilengkapi CCTV [8].

3. Bermodalkan hasil rekaman CCTV anggota polisi, menangkap M Herman. Pelaku pencurian motor [9].

Melihat fakta-fakta diatas penggunaan CCTV menunjukan angka yang signifikan dalam masyarakat. Masyarakat meyakinibahwa penggunaaan CCTV dapat membantu dalam memberikan rasa aman bagi mereka terhadap gangguan keamanan. Namun yang menjadi persoalan walaupun CCTV marak digunakan oleh masyarakat dalam membantu mengungkap timbulnya kejahatan,tetapi dalam Pasal 184 KUHAP dan Hukum Pidana Islam tidak mengatur CCTV sebagai alat bukti.

CCTVmemiliki kelebihan dalam memberikan petunjuk karena didalamnya terdapat teknologi yang dapat digunakan untuk merekam semua kejadian-kejadian baik hal yang terkecil sekalipun.Tidak seperti ingatan manusia yang dapat berubah-ubah memberikan keterangan sesuai dengan kondisi ingatan dan situasi kondisi tertentu dibawah tekanan mental dan fisik.

\section{Metode Penelitian}

Peneliti dalam skripsi ini menggunakan jenis penelitian bersifat yuridis normatif yaitu mengacu kepada norma hukum yang terdapat dalam peraturanperundang-undangan dan putusan pengadilan serta norma-norma yang hidup dan berkembang dalam masyarakat. Populasi disini ialah pihak-pihak yang terlibat dalam peradilan pidana. Sedangkan sample berjumlah 4 orang yang dibagi lagi menjadi 2 penyidik Polresta Palembang dan 2 Hakim Pengadilan Negeri kelas 1A Palembang dengan menggunakan teknik purposive sampling (ditentukan oleh peneliti berdasarkan kemauanya). Peneliti dalam menganalisa data menggunakan analisa bersifat deskriptif analitis, analisis data yang dipergunakan adalah pendekatan kualitatif terhadap data primer dan data sekunder. Deskriptif tersebut, meliputi isi dan struktur Hukum Positif, yaitu suatu kegiatan yang dilakukan oleh penulis untuk menentukan isi atau makna aturan hukum yang dijadikan rujukan dalam menyelesaikan permasalahan hukum yang menjadi objek kajian. 


\section{Darus Harizona}

Kekuatan Bukti Elektronik Sebagai Bukti di Pengadilan Menurut Hukum Acara Pidana dan Hukum Islam (Penggunaan Rekaman Gambar closed Circuit Television)

\section{Hasil dan Pembahasan}

\section{Kedudukan Bukti Elektronik (Rekaman Gambar CCTV) dalam Sistem Pembuktian Pidana (Pasal 181 KUHAP)}

Sebelum menjawab penggunaan rekaman gambar CCTV atau Closed Circuit Television didalam sistem pembuktian pidana, ada baiknya penulis kemukakan apa yang dimaksud dengan CCTV. CCTV adalah alat perekaman yang menghasilkan data video atau audio dan sangat bermanfaat khusus nya dalam hal pengamanan dan merekam segala bentuk aktifitas.Sebagian masyarakat meyakini bahwa penggunaan CCTV dapat membantu memberikan rasa aman serta dapat mengungkap timbulnya kejahatan karena memilki teknologi yang dapat merekam aktifitas yang menjadi objek dari CCTV.

CCTV memiliki kemampuan teknologi untuk merekam dapat menunjang dan membantu proses pembuktian tentu tidak dapat diragukan lagi. Tidak seperti ingatan manusia yang berubah-ubah dalam memberikan keterangan sesuai kondisi tertentu di bawah tekanan mental dan fisik. Maka mengenai hal ini dapat dihubungkan dengan salah satu tujuan Hukum Acara Pidana yaitu untuk mencari dan menemukan kebenaran materil yaitu kebenaran yang selengkap-lengkapnya dari terjadinya suatu tindak pidana.

CCTV yang memiliki kemampuan dalam merekam gambar tentu dapat memberikan manfaat kepada pihak yang menggunakan CCTV dengan cara memberikan sugesti yaitu suatu perasaan aman disebabkan kemampuan merekam objek yang ada disekitar CCTV, serta rekaman gambar CCTV dapat merekam sangat lengkap mengenai suatu persitiwa dan hal- hal lainya seperti waktu dan benda serta warna yang ada dalam rekaman gambar CCTV.

Selain itu CCTV juga telah mengalami perkembangan mengikuti ilmu pengetahuan dan teknologi pada umumnya, sehingga tingkat resolusi gambar semakin baik.Selain itu, terhubung dengan jaringan internet yang mengakibatkan dapat melakukan pemantauan melalui jaringan internet dan penggunanya dapat secara online.Hal ini menyebabkan sebagian pihak yang menggunakan CCTV bisa menjaga harta nya melalui pemantauan lewat CCTV.

CCTV yang memiliki kemampuan dalam merekam tentu dapat berguna apabila terjadi suatu tindak pidana yang terekam oleh CCTV. Oleh sebab itu, CCTV dapat dijadikan sebagai bukti melalui proses penegakan hukum pidana. Penegakan hukum pidana telah diatur secara Integrated criminal justice yaitu sistem peradilan pidana yang mengatur bagaimana penegakan hukum pidana dijalankan. Sistem tersebut mengatur bagaimana proses berjalannya suatu perkara mulai dari penyelidikan, penyidikan, penuntutan sampai pemasyarakatan yang bertujuan untuk menegakan hukum pidana materil.

Proses penyelidikan dan penyidikan yaitu untuk membuat terang suatu perkara pidana, dengan cara mengumpulkan semua alat bukti yang dimungkinkan terdapat hubungan dengan peristiwa pidana. Dalam hal ini bertujuan untuk melakukan penegakan hukum pidana melalui proses pembuktian dalam Pasal 183 
KUHAP yaitu pembuktian berdasarkan undang-undang secara negative (negative wettelijk), Hakim tidak boleh menjatuhkan pidana kepada seseorang kecuali apabila dengan sekurang-kurangnya dua alat bukti yang sah ia memperoleh keyakinan bahwa suatu tindak pidana benar-benar terjadi dan bahwa terdakwalah yang bersalah melakukannya.

Tindakan penyidik sangat penting dalam proses pembuktian karena penyidik memiliki wewenang yang sangat besar dalam mengarahkan pembuktian dengan cara menyiapkan hasil pemeriksaan sebagai berkas perkara. Berkas perkara hasil penyelidikan dilimpahkan kepada penuntut umum dimuka persidangan sehingga tersangka dapat dituntut kemudian dipidana.Oleh karena itu, penyidik melakukan tindakan penyidikan yaitu mengumpulkan bukti yang dengan bukti itu dapat membuat terang tindak pidana dan guna menemukan siapa tersangka.Dalam hal ini apabila terjadi tindak pidana penyidik mencari dan mengumpulkan bukti termasuk rekaman gambar CCTV bila terdapat bukti rekaman gambar CCTV didalam perkara pidana tersebut.

Hal ini juga sebagaimana telah disampaikan oleh dua orang responden penyidik di Porlesta Palembang yang diwawancara oleh penulis yaitu penyidik 1 dan penyidik 2 atas pertanyaan penulis tentang pendapat penyidik terhadap rekaman gambar CCTV.

Hasil wawancara terhadap responden penyidik 1:

"Rekaman gambar CCTV dapat dijadikan alat bukti petunjuk tapi tidak mutlak sebagai alat bukti. Karena itu rekaman gambar CCTV tidak bisa berdiri sendiri sebagai alat bukti, Rekaman gambar CCTV memiliki nilai yang sangat kuat untuk menyakinkan orang bahwa telah terjadi tindak pidana serta hal yang secara umum sudah diketahui tidak perlu di buktikan misalanya CCTV digunakan sebagai alat perekam yang digunakan sebagai pengawasan akan tetapi CCTV bisa juga diperkuat oleh keterangan ahli bila terdapat keraguan didalam hasil rekaman gambar."

Wawancara terhadap responden Penyidik 1:

"Proses pemeriksaan awal yaitu penyidikan dan penyelidikan itu lah yang digunakan untuk membuat terang suatu pidana dengan cara mengumpulkan seluruh barang bukti termasuk rekaman gambar CCTV bila terdapat CCTV dilokasi suatu tindak pidana. CCTV dapat berperan apabila ada dua orang saksi saling persesuaian keteranganya dan ditemukan rekaman gambar CCTV juga persesuian dengan saksi didalam kejadian perkara hal ini meyebabkan rekaman gambar CCTV menjadi kuat sebagai alat bukti petunjuk."

Dalam hal ini CCTV dapat dijadikan oleh penyidik sebagai bukti permulaan dalam proses penyidikan untuk menentukan tersangkanya yaitu sebagai bukti petunjuk. Meskipun tidak mutlak menjadi bukti petunjuk, karena petunjuk harus dipersesuaikan dengan alat bukti lain agar dapat digunakan oleh hakim dalam proses persidangan untuk menjatuhkan pidana.

Seperti yang diketahui bahwa CCTV walaupun memiliki teknologi canggih untuk merekam suatu kejadian, CCTV juga telah digunakan masyarakat sebagai alat 


\section{Darus Harizona}

Kekuatan Bukti Elektronik Sebagai Bukti di Pengadilan Menurut Hukum Acara Pidana dan Hukum Islam (Penggunaan Rekaman Gambar closed Circuit Television)

pengamanan untuk mengawasi.Oleh karena itu, CCTV dapat membantu penyidik dalam membuat terang suatu perkara pidana.Akan tetapi, seperti yang diketahui dalam Pasal 184 KUHAP tidak diatur penggunan rekaman gambar CCTV sebagai alat bukti.Oleh karena itu, hal ini menjadi persoalan karena didalam prakteknya CCTV dapat membantu membuat terang suatu perkara pidana dengan dijadikan penyidik sebagai petunjuk.

Pengertian petunjuk sebagaimana diatur dalam Pasal 188 KUHAP yang merumuskan bahwa:

"Petunjuk adalah perbuatan, kejadian atau keadaan yang karena persesuaiannya, baik antara satu dengan yang lain, maupun dengan tindak pidana itu sendiri, menandakan bahwa telah terjadi suatu tindak pidana dan siapa pelakunya.

Petunjuk hanya dapat diperoleh dari keterangan saksi, surat dan keterangan terdakwa. Terlebih jika diperhatikan pada Pasal 188 ayat (1) KUHAP yang mengatakan bahwa penilaian atas kekuatan pembuktian dari suatu petunjuk dalam setiap keadaan tertentu dilakukan oleh hakim dengan arif lagi bijaksana, setelah ia mengadakan pemeriksaan dengan penuh kecermatan dan kesaksamaan berdasarkan hati nuraninya.

Sedangkan menurut M. Yahya Harahap memberikan pengertian petunjuk dengan menambah beberapa kata, petunjuk ialah suatu "isyarat" yang dapat "ditarik dari suatu perbuatan, kejadian atau keadaan" dimana isyarat tadi mempunyai "persesuaian" antara yang satu dengan yang lain maupun isyarat tadi mempunyai persesuaian dengan tindak pidana itu sendiri, dan dari isyarat yang bersesuaian tersebut "melahirkan" atau "mewujudkan" suatu petunjuk yang "membentuk kenyataan" terjadi suatu tindak pidana dan terdakwalah pelakunya. Berdasarkan pengertian petunjuk yang disampaikan oleh $\mathrm{M}$ Yahya Harahap, apabila dikiatkan dengan CCTV bisa menjadi petunjuk apabila memiliki persesuaian dengan bukti lain. Rekaman gambar CCTV dapat memiliki persesuaian dengan bukti lain, karena CCTV dapat memperlihatkan dan menghubungkan keterangan yang ada sehingga timbul suatu kenyataan melalui hasil rekaman yang bisa memperkuat bukti lain misalnya, keterangan saksi bisa dibenarkan melalui rekaman gambar CCTV.

Dalam hal ini, rekaman gambar CCTV dapat digunakan sebagai bukti didalam proses persidangan yang penilaiannya dilakukan oleh Hakim dengan arif dan bijaksana yaitu ukuranya berupa unsur yuridis, filosofis dan sosiologis sebagaimana yang disampaikan oleh Rifai Achmad, (Rifai, 2011) yaitu 1) Unsur yuridis, yaitu dari segi kepastian hukumnya; 2) Unsur filosofis, yaitu dari segi keadilan; dan 3) Unsur sosilogis, yaitu dari segi kemanfaatanya.

Menurut Mertokusumo [7], ketiga unsur menjadi ukuran apabila hakim hendak mengambil suatu keputusan. Karena itulah di dalam Pasal 197 ayat 1 huruf b berisi Hakim harus mempertimbangkan secara ringkas mengenai fakta dan keadaan beserta alat pembuktian yang diperoleh dari pemeriksaan disidang. Oleh sebab itu, hakim sidang memperlihatkan kepada terdakwa segala barang bukti serta menanyakan apakah mengenal benda itu menurut Pasal 181 KUHAP. 
Oleh sebab itu, rekaman gambar CCTV dalam tindak pidana umum digunakan sebagai petunjuk, serta penilaian atas kekuatan pembuktian dari suatu petunjuk dalam setiap keadaan tertentu dilakukan oleh hakim.Penilaian hakim di lakukan secara yuridis, filosofis dan sosiologis. Hal ini juga didukung oleh hasil wawancara yang dilakukan oleh penulis kepada Hakim Pengadilan Negeri Klas 1 A Palembang yaitu berupa pendapat Hakim terhadap bukti rekaman gambar CCTV sebagai berikut:

"Rekaman Gambar CCTV tidak dapat menjadi alat bukti yang berdiri sendiri pada tindak pidana umum, akan tetapi dalam tindak pidana khusus dapat menjadi alat bukti yang sah yaitu alat bukti elektronik, rekaman gambar CCTV digunakan sebagai petunjuk tetapi melalu persesuaian dengan alat bukti yang lain yang telah diperiksa. Mengenai pengaruh alat bukti rekaman gambar CCTV terhadap keyakinan hakim tergantung dari proses awal pemeriksaan serta pengambilan rekaman gambar CCTV."

Penulis dalam melakukan wawancara terhadap Hakim Pengadilan Negeri klas 1 A Palembang hanya bisa mewawancarai satu orang Hakim, karena hanya mendapat ijin oleh ketua Pengadilan hanya boleh satu orang Hakim untuk diwawancarai. Oleh sebab itu, untuk memenuhi unsur relevasi suatu penelitian, penulis menggunakan putusan pengadilan yang berkaitan dengan penggunaan CCTV sebagai bukti untuk memenuhi unsur relevasi suatu penelitian. Putusan itu adalah sebagai berikut:

Putusan Pengadilan Palembang Nomor: 227 / Pid.B / Palembang / PN Plg. mengenai kasus pencurian dengan kekerasan. Putusan ini menyatakan bahwa terdakwa terbukti sah bersalah dengan berdasarkan keterangan saksi, rekaman gambar CCTV dan keterangan terdakwa. Dalam putusan ini walaupun rekaman gambar CCTV tidak melihat suatu peristiwa pidana, tetapi rekaman ini menjadi petunjuk bagi hakim untuk menghubungkan alat bukti keterangan saksi dan keterangan terdakwa, sehingga memiliki persesuaian satu sama lainya dan membentuk suatu kenyataan bahwa telah terjadi tindak pidana dan terdakwa lah pelakunya, jadi dapat diketahui bahwa hakim telah menggunakan rekaman gambar CCTV sebagai bukti petunjuk.

Seperti yang telah diketahui hakim dalam menjatuhkan putusan menggunakan unsur yuridis, unsur filosofis dan unsur sosiologis yang pengertiannya adalah unsur yuridis yaitu undang undang yang berkaitan dengan tindak pidana, unsur filosofis berintikan kebenaran dan keadilan, unsur sosiologis yaitu mempertimbangkan kemanfaatan dan tata nilai budaya yang hidup serta berkembang dalam masyarakat.

Unsur yuridis dalam perkara ini yaitu : terdakwa telah terbukti melakukan tindak pidana umum melalui proses pembuktian dipersidangan, sebagaimana dakwaan yang diatur dalam Pasal 365 Ayat (1), Ayat (2) ke-2, Ayat (3) KUHP, yaitu unsur-unsurnya yang telah terpenuhi adalah sebagai berikut:

a. Barang siapa;

b. Mengambil sesuatu barang yang seluruhnya atau sebagian kepunyaan orang lain; 


\section{Darus Harizona}

Kekuatan Bukti Elektronik Sebagai Bukti di Pengadilan Menurut Hukum Acara Pidana dan Hukum Islam (Penggunaan Rekaman Gambar closed Circuit Television)

c. Dengan maksud untuk dimiliki sendiri secara melawan hukum, yang didahului, disertai atau diikuti dengan kekerasan atau ancaman kekerasan, terhadap orang dengan maksud untuk mempersiapkan atau mempermudah pencurian, atau dalam hal tertangkap tangan,untuk memungkinkan melarikan diri sendiri atau peserta lainnya, atau untuk tetap menguasai barang yang dicuri;

d. Yang dilakukan oleh dua orang atau lebih dengan bersekutu ;

e. Perbuatan itu menyebabkan orang mati.

Unsur filosofis dalam perkara ini yaitu : dalam persidangan, majelis hakim tidak menemukan hal-hal yang dapat menghapuskan pertanggung jawaban pidana, baik sebagai alasan pembenar dan atau alasan pemaaf, maka terdakwa harus mempertanggung jawabkan perbuatannya, bahwa oleh karena terdakwa mampu bertanggung jawab, maka harus dinyatakan bersalah dan dijatuhi pidana. Bahwa dalam perkara diatas juga terhadap terdakwa telah dikenakan penangkapan dan penahanan yang sah, maka masa penangkapan dan penahanan tersebut harus dikurangkan seluruhnya dari pidana yang dijatuhkan, bahwa oleh karena terdakwa ditahan dan penahanan terhadap terdakwa dilandasi alasan yang cukup, maka perlu ditetapkan agar terdakwa tetap berada dalam tahanan

Unsur sosiologis dalam perkara ini yaitu: hakim dalam memutuskan untuk menjatuhkan pidana terhadap terdakwa, maka perlu dipertimbangkan terlebih dahulu keadaan yang memberatkan dan yang meringankan terdakwa. Keadaan yang memberatkan yaitu Perbuatan terdakwa telah mengakibatkan kematian Korban terdakwa tidak menyesali perbuatannya, terdakwa memberikan keterangan yang berbelit-belit, terdakwa sudah pernah dijatuhi pidana.Sedangkan keadaan yang meringankan yaitu terdakwa memiliki tanggungan isteri dan anak.

Berdasarkan unsur diatas dapat dilihat bahwa unsur yuridis (kepastian hukum), filosofis (keadilan) dan sosiologis (kemanfaatan) sudah terpenuhi.Seperti yang disampaikan oleh Mertokusumo bahwa ketiga unsur tersebut harus ada dalam suatu keputusan hakim.Unsur filosofis didalam putusan diatas dapat dilihat bahwa hakim membenarkan melalui alasan yang cukup suatu penahanan melalui petunjuk rekaman gambar CCTV bisa dilakukan dan hal itu juga telihat dapat mempengaruhi suatu putusan hakim.

Selain itu penulis juga menggunakan undang-undang tindak pidana khusus sebagai perbandingan yaitu Undang-Undang Nomor 11 Tahun 2008 tentang Informasi dan Transaksi Eletronik lah, menjelaskan bahwa rekaman gambar CCTV dapat digolongkan sebagai informasi elektronik sebagaimana dinyatakan dalam Pasal 1 ayat (1) yang merumuskan bahwa:

"Informasi Elektronik adalah suatu atau sekumpulan data elektronik, termasuk tetapi tidak terbatas pada tulisan, suara, gambar, peta,rancangan, foto, Electronic Data Interchange (IDE), surat elektronik (electronic mail), telegram, teleks, telecopy atau sejenisnya, huruf, tanda, angka, kodem akses, simbol atau perforasi yang telah 
diolah yang memiliki arti atau dapat dipahami oleh orang yang mampu memahaminya."

Pasal 1 ayat (4), yang merumuskan:

"Dokumen Elektronik adalah setiap informasi elektronik dibuat, diteruskan, dikirimkan, diterima, atau disimpan dalam bentuk analog digital, elektromagnetik, optikal, atau sejenisnya yang dapat dilihat, ditampilkan, dan/atau didengar melalui komputer atau sistem elektronik termasuk tetapi tidak terbatas pada tulisan, suara, gambar, peta, rancangan, foto, atau sejenisnya huruf, tanda, angka, kode akses, simbol atau perforasi yang memiliki makna atau arti atau dapat dipahami oleh barang yang mampu memahaminya.

Pasal 44 Undang-Undang No. 11 Tahun 2008 tentang Informasi dan Transaksi Elektronik merumuskan: Alat bukti penyidikan, penuntutan dan pemeriksaan di sidang pengadilan menurut ketentuan Undang-Undang ini adalah sebagai berikut:

a. Alat bukti sebagaimana dimaksud dalam ketentuan Perundang-Undangan; dan

b. Alat bukti lain berupa Informasi dan/atau Dokumen Elektronik sebagaimana dimaksud dalam Pasal 1 angka 1 dan angka 4 serta Pasal 5 ayat (1), ayat (2), dan ayat (3)

Undang-Undang No 11 Tahun 2008 Tentang Informasi dan Transaksi Pasal 5 sebagai berikut:

a. Informasi elektronik dan atau dokumen elektronik dan atau hasil cetaknya merupakan alat bukti yang sah.

b. Informasi elektronik dan atau dokumen elektronik dan atau hasil cetaknya merupakan perluasan dari alat bukti yang sah sesuai dengan Hukum Acara Yang berlaku di Indonesia.

1) Informasi elektronik dan atau dokumen elektronik dinyatakan sah apabila menggunakan ketentuan yang diatur dalam undang-undang ini.

2) Ketentuan mengenai informasi eletronik dan atau dokumen eletronik tidak berlaku untuk hal-hal sebagai berikut:

a) Surat yang menurut undang-undang harus dibuat secara tertulis.

b) Surat beserta dokumennya yang menurut undang-undang harus dibuat dalam bentuk akta notaris atau akta yang dibuat oleh pejabat pembuat akta.

Berdasarkan undang-undang ini jelas lah bahwa rekaman gambar CCTV adalah sebagai informasi dan dokumen elektronik, jadi rekaman gambar CCTV adalah sebagai alat bukti yang sah selama digunakan menurut undang-undang ini yaitu dalam undangundang tindak pidana khusus, rekaman gambar CCTV adalah alat bukti elektronik. Rekaman gambar CCTV adalah informasi dan/atau dokumen elektronik jadi dalam hal 


\section{Darus Harizona}

Kekuatan Bukti Elektronik Sebagai Bukti di Pengadilan Menurut Hukum Acara Pidana dan Hukum Islam (Penggunaan Rekaman Gambar closed Circuit Television)

ini dapat direkayasa, maka dari itu diperlukan keterangan ahli yaitu keterangan ahli dapat diuraikan sebagai berikut:

Menurut Pasal 1 angka 28 KUHAP, bahwa

"Keterangan ahli adalah keterangan yang diberikan oleh seorang yang memiliki keahlian khusus tentang hal yang diperlukan untuk membuat terang suatu perkara pidana guna kepentingan pemeriksaan."

Menurut Pasal 186 KUHAP, bahwa Keterangan ahli ialah apa yang seorang ahli nyatakan di sidang pengadilan. Jika mengacu pada bentuk rekaman gambar CCTV sebagai alat bukti elektronik, jelas bahwa rekaman gambar CCTV tidak dapat digolongkan dalam keterangan ahli.Hal ini juga didukung oleh wawancara yang dilakukan oleh penulis terhadap responden 2 penyidik dan 1 Hakim.

Wawancara terhadap responden penyidik 1 dan 2 dengan pertanyaan apakah CCTV bisa jadi keterangan ahli dan pernah adakah rekayasa terhadap rekaman gambar CCTV di wilayah penyidikan Porlesta Palembang:

"Penyidik 1 dan 2 sepakat bahwa CCTV bukan lah keterangan ahli.tetapi keterangan ahli diperlukan apa bila terdapat keraguan didalam rekaman gambar itu dalam pemeriksaan awal dan digunakan sebagai petunjuk untuk menemukan bukti lain serta harus disesuaikan dengan alat bukti lain, mengenai rekaman gambar CCTV yang direkayasa belum ditemukan hal tersebut."

Sedangkan terhadap wawancara responden Hakim atas pertanyaan yang sama yaitu apakah rekaman gambar CCTV bisa dijadikan keterangan ahli dan pernah kah ditemukan didalam persidangan dipengadilan Negeri Klas 1 A Palembang Hakim berkeyakinan dan menemukan rekayasa terhadap rekaman gambar CCTV:

"Hakim beranggapan bahwa rekaman gambar CCTV bukan lah keterangan ahli akan tetapi Hakim dapat meminta ahli agar menjelaskan dan menerangakan isi dari CCTV yaitu rekaman gambar, jadi keterangan ahli bila di hubungan dengan rekaman gambar CCTV hanya sebagai penujang untuk memperkuat keyakinan hakim terhadap rekaman gambar mengenai rekayasa Hakim belum pernah menemukan adanya kasus rekayasa terhadap rekaman gambar CCTV"

Berdasarkan penjelasan diatas, CCTV bukan lah alat bukti Keterangan ahli, serta keterangan ahli hanya untuk menguatkan dipersidangan jadi kekuatannya sebagai bukti ditentukan oleh Hakim dengan arif dan bijaksana secara yuridis, filosofis dan sosiologis dalam tindak pidana umum maupun tindak pidana khusus. Serta mengenai rekaman gambar CCTV yang di rekayasa belum pernah ditemukan baik dalam penyelidikan di Porlesta Palembang serta persidangan Pengadilan Negeri Klas 1 A Palembang.

Rekaman gambar CCTV menjadi terpengaruh kedudukanya akibat Putusan Mahkamah Konstitusi No. 20/PUU-XIV/2016. Perkara tersebut bermula dari keberatan pihak pemohon atas rekaman suaranya yang dipakai sebagai bukti dugaan adanya 
semacam 'persekongkolan' dengan alasan bahwa informasi/dokumen elektronik bukan alat bukti yang sah apa bila tidak dibuat oleh penegak hukum.

Oleh karenanya, melalui Putusan MK Nomor: 20/PUU-XIV/2016 pada tanggal 7 September 2016 lalu, menyatakan bahwa khusus bukti elektronik (informasi/dokumen elektronik) harus dimaknai "sebagai alat bukti dilakukan dalam rangka penegakan hukum atas permintaan kepolisian, kejaksaan dan/atau institusi penegak hukum lainnya yang ditetapkan berdasarkan undang-undang ". Sebagai lembaga sah satu-satunya yang melakukan penafsiran konstitusi (the sole interpreter of constitution) atas legalitas undang-undang, disini MK melakukan penafsiran sendiri agar tidak terjadi tindakan kewenang-wenangan (tidak sah) terutama oleh aparat penegak hukum dalam mengajukan alat bukti elektronik.

Advokat Hotman Paris Hutapea juga menyatakan CCTV bukan lah alat bukti, sebagaimana dilaporkan oleh Mihardi dari sindonews.com bahwa alat bukti rekaman gambar CCTV karena dibuat bukan atas permintaan penyidik sehingga sesuai putusan Mahkamah Konstitusi No. 20/PUU-XIV/2016 tidaklah sebagai alat bukti.

Menurut penulis tidak semua perekaman itu illegal jadinya.Tempat umum juga bukanlah ranah berprivasi.CCTV bukanlah alat penyadapan (intersepsi), melainkan alat pengawasan sehingga CCTV bukanlah bagian dari pelanggaran privasi bila berada di tempat umum.Jadi, dari putusan MK ini diperlukan penafsiran lagi dalam hal ini penulis menyimpulkan bahwa dalam pembuatan alat bukti elektronik haruslah yang diperoleh atas permintaan (dimintakan oleh/melibatkan) aparat penegak hukum dan sekali lagi tak ada kaitannya dengan cara pembuatan alat bukti.

Berdasarkan seluruh uraian diatas, maka penulis dapat simpulkan bahwa kedudukan rekaman gambar CCTV, menurut sistem pembuktian hukum acara pidana dalam Pasal 181 KUHAP.Dalam prakteknya didapati sebagai alat bukti, namun bukanlah alat bukti yang berdiri sendiri tetapi alat bukti yang ditentukan oleh hakim.Hakim dalam menetukan keputusannya berdasarkan ukuran yuridis, filosofis dan sosiologis yaitu secara arif dan bijaksana. Dalam hal ini, hakim akan melihat persesuian rekaman gambar CCTV dengan alat bukti lain. Sehingga rekaman gambar CCTV tersebut dapat digunakan sebagai alat bukti dalam perkara pidana yang dihadapinya.

\section{Kedudukan Bukti Elektronik (Rekaman Gambar CCTV) dalam Fiqh Jinayah}

Seperti yang diketahui bahwa Hukum Islam bertujuan untuk memenuhi kepentingan kebahagian, kesejahteraan dan keselamatan hidup didunia dan diakhirat. Dalam hal ini, rekaman gambar CCTV bisa menjadi salah satu alat untuk tujuan Hukum Islam tersebut, karena rekaman gambar CCTV mampu merekam dengan resolusi gambar yang baik. Selain itu bisa terhubung dengan jaringan internet sehingga pihak yang menggunakan bisa melakukan pemantauan melalui jaringan internet secara online selama terhubung dengan jaringan internet.Hal ini lah yang menyebabkan sebagian pihak yang menggunakan CCTV memanfaatkannya untuk menjaga harta nya yang 


\section{Darus Harizona}

Kekuatan Bukti Elektronik Sebagai Bukti di Pengadilan Menurut Hukum Acara Pidana dan Hukum Islam (Penggunaan Rekaman Gambar closed Circuit Television)

menjadi salah satu sumber kebahagian dan kesejateraannya melalui pemantauan lewat CCTV dan juga pemberi rasa aman sebagaimana yang telah dijelaskan terdahulu.

Menjaga keselamatan hidup juga salah satunya tidak di perlakukan sewenangwenang.Dalam hal ini apabila seseorang dituduh melakukan kejahatan maka diperlukan pembuktian secara adil.Oleh sebab itu, CCTV dapat berperan sebagai suatu petunjuk apakah terdapat suatu tindak pidana, namun sebagai petunjuk sendiri harus ditentukan oleh hakim dengan arif dan bijaksana mengenai apakah bisa atau tidak menjadi petunjuk didalam persidangan menurut Hukum Acara pidana.meskipun demikian alat bukti CCTV harus diteliti lebih dahulu apakah terdapat rekayasa didalam rekaman gambar CCTV tersebut agar bisa digunakan menjadi bukti yang sah dalam proses pembuktian dipersidangan sebagaimana penelitian terdahulu jelaskan. Sedangkan penggunaan rekaman gambar CCTV didalam Fiqh Jinayah dapat dijelaskan didalam proses pembuktian fiqh jinayah yaitu merupakan sesuatu hal yang sangat penting, sebab pembuktian merupakan esensi dari suatu persidangan guna mendapatkan kebenaran yang mendekati kesempurnaan.(Al-Bayyinah) adalah sebagai segala sesuatu yang dapat digunakan untuk menjelaskan yang haq (benar) didepan majelis hakim, baik berupa keterangan, saksi dan berbagai indikasi yang dapat dijadikan pedoman oleh majelis hakim untuk mengembalikan hak kepada pemiliknya.

Pembuktian merupakan salah satu tahapan yang menjadi prioritas yang harus dipenuhi dalam penyelesaian suatu sengketa pidana.hal ini karena dalam penyelesaian sengketa pidana terdapat kemaslahatan serta akan menolak kemudaratan, karena dengan pembuktian menghidarkan seseorang yang tidak bersalah dihukum, hal ini sesuai dengan kaidah Fiqh Jinayah :

"Hindari lah hukuman Had jika terdapat syubhat"

Bukti dalam kaidah Hukum Acara menurut syariat Islam dalam pembuktian ini lah yang digunakan sebagai Hujjah (alasan Hukum) berdampak kepada terkena atau tidaknya hukuman, serta dalam menghidarkan dalam perkara syubhat, alat bukti dan barang bukti dalam Hukum Islam tidak memiliki perbedaan karena dalam Hukum Islam segala sesuatu yang menerangkan dan menjelaskan yang $\mathrm{Haq}$ (kebenaran) ialah $\mathrm{Al}$ Bayinah sebagai pembuktian.

Mengenai alat bukti rekaman gambar CCTV seperti yang telah diketahui bahwa didalam Hukum Acara Pidana ditindak pidana umum dijadian sebagai petunjuk yang harus di persesuaikan dengan alat bukti lain, sedangkan di dalam tindak pidana khusus rekaman gambar CCTV di jadikan sebagai alat bukti elektronik. Hal ini tidak berbeda dengan Hukum Islam bahwa rekaman gambar CCTV di jadikan sebagai petunjuk.Menurut pandangan Muhammad Az-Zuhaili, qarinah mengalami perkembangan sesuai dengan kondisi dan situasi juga perkembangan ilmu pengetahuan dan teknologi. Contoh-contoh qarinah antara lain; analisa, sidik jari, foto, rekaman suara, rekaman suara dan gambar seperti CCTV, sidik jari genetis, DNA dan lain-lain 
Az-Zuhaili berpendapat bahwa qarinah hanya sebagai sarana pelengkap ketika hakim tidak bisa menemukan bukti-bukti lain yang jelas, atau ketika bukti- bukti yang ada tidak mencukupi atau memuaskan.Dengan demikian, qarinah selalu bergandengan dengan alat bukti utama, fungsinya untuk lebih memperkuat dan meyakinkan.Hal ini tidak terlepas dari kurang meyakinkannya rekaman gambar CCTV.Sedangkan dalam memvonis sebuah kasus, apalagi dalam kasus pidana harus didasarkan kepada bukti yang meyakinkan.Persoalan ini, sejalan dengan kaidah yang dikutip dari hadits lebih baik salah memaafkan dari pada salah menghukumi.Al Qara-in atau Qarinah diambil dari kata muqaranah (penyertaan). Dalam Thuruqul Qadla Pentujuk itu bisa kuat atau lemah, dan bisa ketingkatan pasti. Ukuran dalam menetapkannya, ialah kepada kuat pikiran, kecerdasan dan kebajikan. Sedangkan secara istilah dapat diartikan tanda-tanda yang merupakan hasil kesimpulan hakim dalam menangani berbagai kasus melalui ijtihad.Al-majalah al-adliyah mempergunakan qarinah sebagai bukti.

Berbeda dengan Az-Zuhaili, Ibnu Qayyim Al-Jauziyah, sebagaimana telah dijelaskan pada bagian definisi bayyinah.Qarinah atau CCTV, menurut Ibnu Qayyim dapat dijadikan sebagai alat bukti dalam berbagai kasus baik perdata maupun pidana. Lebih lanjut Ibnu Qayyim menegaskan bahwa jika hakim mengabaikan qarinah sebagai alat bukti, maka ia telah melukai rasa keadilan dan telah melakukan kesalahan yang sangat fatal.

Penggunaan alat bukti qarinah itu sendiri dikemukakan dalam al-Qur'an, dalam kisah nabi Yusuf dengan putri Zulaikha tentang bagaimana alat bukti petunjuk berperan untuk membuktikan dakwaan berbuat tidak senonoh yang dituduhkan Zulaikha kepada yusuf.Dalam hal ini yang menjadi petunjuk adalah robekan baju di bagian punggung Yusuf.

Dalam suatu sengketa anak antara dua orang ibu yang sama-sama mengaku bahwa anak tersebut adalah miliknya.Kemudian kasus ini dibawa kapada nabi Daud dan kemudian nabi Daud memutuskan anak itu untuk yang lebih tua.sulaiman yang hadir pada saat itu meminta sebilah pisau dan mengatakan akan membelah anak tersebut menjadi dua. Melihat hal itu ibu yang lebih muda memilih membiarkan anak tersebut diberikan kepada yang lebih tua.Melihat hal ini kemudian anak itu diputuskan milik ibu yang lebih muda.

Dalam hal ini yang menjadi qarinah dan menjadi bukti kebohongan adalah teganya seorang ibu akan kematian anaknya, padahal sebelumnya mereka bersengketa tentang hak siapa anak tersebut. Anak yang disengketakan tersebut diberikan oleh Sulaiman kepada ibu yang lebih muda karena sikapnya yang menunjukkan bahwa dialah ibu yang berhak terhadap anak itu.Keberadaan alat bukti qarinah itu sendiri sering dilalaikan oleh pihak-pihak yang bersengketa maupun pihak pengadilan.

Dari paparan diatas penulis dapat disimpulkan bahwa dalam menyikapi kedudukan rekaman gambar CCTV didalam Fiqh jinayah, rekaman gambar CCTV dapat dijadikan alat bukti pendukung yaitu sebagai petunjuk yang menguatkan bukti lain, serta dengan pengertian kata bayyinah yang bermakna bukti memiliki medan makna yang sangat 


\section{Darus Harizona}

Kekuatan Bukti Elektronik Sebagai Bukti di Pengadilan Menurut Hukum Acara Pidana dan Hukum Islam (Penggunaan Rekaman Gambar closed Circuit Television)

luas bukan hanya manusia sebagai saksi atau alat bukti. Namun juga bermakna segala sesuatu yang bisa menunjukan kebenaran suatu peristiwa atau tindakan. Serta penggunaan rekaman gambar CCTV juga harus diteliti oleh ahli apakah terdapat rekayasa atau tidak agar bisa menjadi petunjuk.

\section{Kesimpulan}

Kedudukan rekaman gambar CCTV, menurut sistem pembuktian hukum acara pidana dalam Pasal 181 KUHAP. Dalam prakteknya didapati sebagai alat bukti, namun bukanlah alat bukti yang berdiri sendiri tetapi alat bukti yang ditentukan oleh hakim. Hakim dalam menetukan keputusannya berdasarkan ukuran yuridis, filosofis dan sosiologis yaitu secara arif dan bijaksana. Dalam hal ini, hakim akan melihat persesuian rekaman gambar CCTV dengan alat bukti lain. Sehingga rekaman gambar CCTV tersebut dapat digunakan sebagai alat bukti dalam perkara pidana yang dihadapinya.

Menyikapi kedudukan rekaman gambar CCTV dalam Fiqh Jinayah. CCTV dapat dijadikan alat bukti pendukung, yaitu sebagai petunjuk yang menguatkan bukti lain. Serta dengan pengertian kata bayyinah yang bermakna bukti memiliki medan makna yang sangat luas bukan hanya manusia sebagai saksi atau alat bukti. Namun juga bermakna segala sesuatu yang bisa menunjukan kebenaran suatu peristiwa atau tindakan. Dalam hal ini, penggunaan rekaman gambar CCTV juga harus diteliti oleh ahli apakah terdapat rekayasa atau tidak, agar bisa menjadi petunjuk. 


\section{Daftar Pustaka}

[1] P. M. Marzuki, Pengantar Ilmu Hukum, Jakarta: Kencana Prenada Media Group, 2013.

[2] A. Hamzah, Asas-asas Hukum Pidana, Jakarta: Rineka Cipta, 2014.

[3] A. Zainudin, Hukum Islam, Jakarta: Sinar Grafika, 2010.

[4] M. N. Irfan, Hukum Pidana Islam, Jakarta : Amzah, 2016.

[5] A. Hamzah, Terminologi Hukum Pidana, Jakarta: Sinar Grafika, 2009.

[6] U. Hasyim, Teori pembuktian Menurut Fiqh Jinayah Islam, Yogyakarta : Andi Offset, 1981.

[7] P. Ekspress, "Pelaku Kejahatan Terekam," Palembang Ekspres, [Online]. Available: https://webpalpres.wordpress.com/. [Accessed 27 Oktober 2016].

[8] H. S. Ekspres, "Keamanan Stasiun Kertalaya," Harian Sumatera Ekspres, [Online]. Available: http://sumeks.co.id/. [Accessed 24 Nopember 2014].

[9] B. Pagi, Berita Pagi. [Online]. [Accessed 26 Agustus 2016].

[10] S. Mertokusumo, Penemuan Hukum (Sebuah Pengantar), Jakarta: Liberty, 2009. 


\section{Darus Harizona}

Kekuatan Bukti Elektronik Sebagai Bukti di Pengadilan Menurut Hukum Acara Pidana dan Hukum Islam (Penggunaan Rekaman Gambar closed Circuit Television) 